\title{
Szakemberek véleménye a klímaválság gyermekekre és fiatalokra gyakorolt hatásáról (szöveghü fordítás)
}

Health Professionals on the Impact of the Climate Crisis on Children and Youth

\begin{tabular}{|c|c|}
\hline Fordította: & Kovács Zsuzsanna \\
\hline $\begin{array}{l}\text { Ismertetett } \\
\text { dokumentum: }\end{array}$ & $\begin{array}{l}\text { Declaration. Responding to the Impact of the Climate Crisis on Children and Youth. } \\
\text { The Role of Child Health Professionals and Organizations In Achieving Climate } \\
\text { Justice. The Climate Crisis is a Child Rights Crisis. } \\
\text { https://www.issop.org/cmdownloads/issop declaration on climate change/ }\end{array}$ \\
\hline $\begin{array}{l}\text { Kulcsszavak: } \\
\text { Keywords: }\end{array}$ & $\begin{array}{l}\text { klímaválság; gyermekek; gyermekjogok } \\
\text { climate crisis; children; child rights }\end{array}$ \\
\hline
\end{tabular}

Beküldve: 2021. 06. 27., doi: $\underline{10.24365 / \text { ef.v62i3.6688 }}$

Deklaráció a klímaválság gyermekekre és fiatalokra gyakorolt hatásáról A gyermekegészségügyi szakemberek és szervezetek szerepe Klímaváltozás és gyermekjogok

\section{BEVEZETÉS}

Az ENSZ Gyermekjogi Egyezménye, valamint a Fenntartható Fejlődési Célok rögzítik, hogy a gyermeknek joga van az őt érintő kérdésekben véleményt nyilvánítani. A klímaváltozás különösen ilyen probléma, így a gyermekek és az őket képviselő mozgalmak világszerte követelik, hogy hallgassák meg a klímaváltozással kapcsolatos nézeteiket. Minden ok megvan az aggodalomra - a The Lancet 2019-es beszámolói, valamint számos egyéb szakmai publikáció kimutatta, hogy a klímaváltozás direkt és indirekt hatásai leginkább a csecsemők és gyermekek egészségét és jóllététét, tehát a jövő nemzedékeit veszélyeztetik.

A klímaválság egyúttal a gyermekjogok válsága. A Gyermekjogi Egyezményben és a Fenntartható Fejlődési Célokban megfogalmazott elvek és normák a klímaváltozással kapcsolatos teendők kidolgozásához is irányt mutatnak.

A gyermekegészségügyi szakemberek azok, akik leginkább észlelik a klímaváltozás káros hatásait, ezért különösen fontos, hogy a fiatalokkal együtt tevékenykedjenek és reagáljanak ezekre a veszélyekre. Mint Nemzetközi Szociálpediátriai Társaság (ISSOP) - a szociálpediátriai és gyermekjogi szempontokat összehangolva - támogatjuk a globális éghajlati válság gyermekekre és fiatalokra gyakorolt hatásainak megelőzését és enyhítését szolgáló szakmaközi stratégiák kialakítását.

Elismerjük az őslakos népek ősi bölcsességét, mellyel a környezetet tiszteletben tartva biztosítják minden ember jogait és a bioszférával összhangban élnek. Minden erőnkkel támogatjuk azokat az intézkedéseket, amelyek biztosítják a fenntartható fejlődést bolygónk valamennyi gyermeke számára.

\section{Ezért:}

Mivel az ENSZ Éghajlatváltozási Kormányközi Testületének (IPCC) negyedik értékelő jelentése szerint a Föld globális éghajlatváltozáson megy keresztül, melyhez jelentősen hozzájárul az emberi tevékenység; és

Mivel az éghajlatváltozás befolyásolja a közegészségügyet, különösen bizonyos életszakaszokra hat, ezen belül fokozottan érinti a szegénységben élő és az alacsony jövedelmű országokban élő gyermekeket; és 
Mivel a növekedésben, fejlődésben lévő gyermekek különösen érzékenyek, mert különleges kölcsönhatásban vannak a környezetükkel és az alapvető szükségleteik kielégítésében szüleikre és gondozóikra kell támaszkodniuk; és

Mivel a hőmérsékletemelkedés a gyermekek egészségére különösen kihat, gyakoribbak, súlyosabbak és tovább tartanak az extrém hőhatások, gyakoribbá válnak az étel, víz vagy vektor által terjesztett vagy mikotoxinok által okozott betegségek. A penészgombák, a pollenek valamint a fosszilis üzemanyagok égéstermékei fokozottabban szennyezik a levegőt. Mindezek mentális stresszt is okoznak; és

Mivel az infrastruktúra megsemmisülése, a vízért, élelmiszerért és egyéb erőforrásokért folytatott versenyből fakadó konfliktusok és a lakhely kényszerű elhagyása egyre inkább hatással lesznek a gyermekek egészségére, mentális egészségére és jóllétére; és

Mivel a konfliktusok nemcsak az éghajlatváltozás következményei, hanem előidézői is, ugyanis a természeti erőforrások egyik fő fogyasztója a fegyvergyártás és fegyverkereskedelem; és

Mivel a digitalizáció rengeteg energiát fogyaszt; és

Mivel a katasztrófák a mentális és érzelmi fejlődésben lévő gyermekekre másképp hatnak, mint az érett felnőttekre; és

Mivel a szakemberek szerint a klímaváltozás veszélyezteti a gyermekek mentális egészségét biztosító társadalmi struktúrákat:

Javasoljuk, hogy a regionális, nemzeti és nemzetközi gyermek- és gyermekegészségügyi szervezetek - egészségügyi szakemberekkel, gyermekvédőkkel, a fiatalokkal és családjaikkal együtt — vállalják, hogy egyénileg és együttesen dolgoznak a fosszilis üzemanyagok használatának minimalizálása, a globális szén-dioxid kibocsátás csökkentése érdekében, az éghajlatváltozásnak a gyermekekre gyakorolt hatásait enyhítve egy ökológiailag fenntartható világban.

\section{Mi, mint nemzeti/nemzetközi gyermek- egészségügyi szakmai szervezet javasoljuk, hogy a szakemberek:}

- A családokkal történő találkozások során az éghajlatváltozás problémáját is érintsék és személyesen is mutassanak példát.

- Szakmai tevékenységükkel járuljanak hozzá, hogy a klímaváltozás enyhítését célzó stratégiák a gyakorlatban is megvalósuljanak pl.: tiszta levegő és víz, tápláló élelmiszerek, parkokhoz és zöldterületekhez való hozzáférés stb.

- Csökkentsék a szakmai találkozókkal járó szén-dioxid-kibocsátást pl.: részesítsék előnyben a környezetbarát megoldásokat pl.: ne repülővel utazzanak, az ellátást "zöld" létesítményekkel és szervezetekkel valósítsák meg, amelyek elsősorban vegetáriánus, éghajlat-tudatos és helyi eredetű ételeket kínálnak stb.

- A szakmai találkozók szponzorálását tegyék függetlenné a tápszer- és bébiételgyártó cégektől és támogassák az anyatejes táplálást, amely nemcsak a gyermek számára optimális, hanem környezetbarát is.

- Lépjenek fel a gyermekeket, mint fogyasztókat kihasználó, a fogyasztást ösztönző üzletpolitika ellen.

- Utasítsák el a szakmai találkozók üzemanyag-ipar által történő szponzorálását.

- Múködjenek együtt azokkal a tudományos és egészségügyi intézményekkel és aktivista csoportokkal, amelyek a klímaváltozás a gyermekek egészségére gyakorolt hatásaival foglalkoznak, azokat elemzik és közzéteszik.

- Tevékenykedjenek az éghajlatváltozás következményei miatt bekövetkező károk kezelésében, ideértve a lakóhelyüket elhagyni kényszerült családok egészségügyi ellátását is (pl.: vektor által terjedő betegségek, hőguta kezelése, oltásokhoz való hozzáférés stb.)

- Vegyenek részt az éghajlatváltozás és az egészségügyi ellátás egyenlőtlenségei közötti összefüggések kutatásában, és járuljanak hozzá ezen egyenlőtlenségek mérsékléséhez. 
- Járuljanak hozzá a katasztrófákra való felkészüléshez, különös tekintettel a gyermekekre és fiatalokra.

- Vásároljanak helyi és újrahasznosított termékeket, és kerüljék az eldobható termékeket.

- Támogassák az egyének és családok reprodukciós jogait (családtervezés, megfelelő szexuális ismeretek, elérhető legmagasabb szintű szexuális és reprodukciós egészségügyi ellátás).

- Vegyenek részt klímavédelemmel kapcsolatos oktató, támogató és civil tevékenységekben.

\section{Népszerüsítsék az oktatást:}

- Gyermekegészségügyi szakemberek körében az éghajlatválság minden aspektusáról: a klímaváltozás tudománya, stratégiák a szén-dioxid-kibocsátás csökkentésére, közvetlen és közvetett hatásai a gyermekek fizikai és mentális egészségére, e hatások megelőzése, hatékony gyermekvédelem.

- A gyermek jogairól minél szélesebb körben, ezen belül arról, hogy a gyermeknek joga van a hangját hallatni az éghajlatváltozás kérdéseiben is (ENSZ CRC 42. cikk).

- A gyermekek és családok körében, az egészségügyi helyiségekben (irodák, klinikák, kórházak), iskolákban, a civil társadalomban és egyéb helyeken, ahol a gyermekek és a felnőttek élnek és tanulnak.

- Szakértőként ismételten hívják fel a megválasztott tisztviselők figyelmét az éghajlatváltozás kockázataira, mely különösen érinti a gyermekek és fiatalok egészségét.

- Civil és szakmai közösségekben támogassák, hogy a gyermekekkel és szervezeteikkel együttműködve javítsák a környezettudatos magatartást.

- Tájékoztassák a szülőket és a gyermekeket a káros média és marketing gyakorlatról, mely a fogyasztást ösztönző üzletpolitikával kizsákmányolja a gyermekeket és emellett hozzájárul a klímaválsághoz.

- Tájékoztassanak azokról a mozgalmakról (pl.: One Health, Planetary Health, Traditional Ecological Knowledge), amelyek világszerte vizsgálják a klímaváltozás társadalmi, gazdasági, kulturális, ökológiai és filozófiai okait és javaslatokat dolgoztak ki ellenálló ökoszisztémák fenntartására, a fajok és a biológiai sokféleség védelmére, valamint az emberi jogok és a társadalmi igazságosság érdekében.

\section{Támogassák:}

- azokat a helyi, nemzeti és nemzetközi stratégiákat, amelyek csökkentik az üvegházhatást okozó gázok kibocsátását és biztosítják az időjárás szélsőséges fordulataira való felkészülést.

- a fenntartható és megújuló energiatermelést, a közösségi közlekedést, a főleg növényi alapú és regeneratív úton előállított élelmiszereket, valamint a zöldterületekhez való egyenlő hozzáférést.

- a fenntartható, széndioxid-semleges, paszszív házak építését és a meglévő lakásállomány korszerűsítését.

- az energiatakarékos módszereket az otthonokban, iskolákban, kórházakban, munkahelyeken stb.

- az alternatív és egészségesebb közlekedési formákat (gyalogos, kerékpár, elektromos járművek, tömegközlekedés).

- a fenntartható fejlődés elveinek gyakorlati megvalósítását.

- a gyermekek és fiatalok klímaválsággal és környezetszennyezéssel szemben kifejtett tevékenységét.

- A kórházak és egészségügyi intézmények környezetvédő tevékenységébe vonják be a személyzetet, a pácienseket és családjaikat is.

- Legyenek az egészségügyi intézmények is energiatakarékos, széndioxid- semleges, környezettudatos létesítmények.

A társadalomnak, ezen belül a gyermekegészségügyi szakembereknek ismerniük kell az emberi tevékenység által is kiváltott éghajlatváltozások által okozott globális veszélyt, mely különösen a gyermekek és fiatalok egészségét és jóllétét fenyegeti. Egyéni és közösségi felelősségünk, hogy megakadályozzuk, legalább enyhítsük ezt a hatást, és biztosítsuk a gyermekek alapvető jogait az optimális túlélésre és fejlődésre. 


\section{TANULSÁGOK A HAZAI SZAKEMBEREK SZÁMÁRA}

Ismeretes, hogy hazánk az EU országai közül az elsők között ratifikálta a Párizsi Megállapodást. Számos program indult, sajnos azonban a klímavédelmi szempontból hazánk igen gyenge eredményt mutat. A 2021-ben végzett felmérés szerint az értékelt 61 országból az 50. helyen állunk. Ismeretes, hogy a környezeti ártalmak így pl. a légszennyezettség a hazai gyermekpopuláció - különösen a hátrányos helyzetű régiókban élők - számára jelentős egészségi ártalmakat okoz. Ezért különösen fontos, hogy a döntéshozók és az ezen a területen múködő civil szervezetek mellett a hazai gyermekegészségügyi szakemberek is járuljanak hozzá a klímavédelemhez:

- mind helyi, mind országos szinten támogassák a klímaváltozás megelőzését célzó programokat, szerezzenek érvényt az egészségügyi szempontoknak,

- személyes példával (közösségi/környezetbarát közlekedés, szelektív hulladékgyűjtés, környezettudatos fogyasztási szokások stb.),

- oktatás, nevelés (családok tájékoztatása, iskolai egészségfejlesztési programokban szerepeljen a klímaváltozás témája is).

\section{HIVATKOZÁSOK}

Ahdoot S. \& Pacheco S.E. (2015). Council on Environmental Health. Global climate change and children's health. Pediatrics, 136(5):e1468-84. doi: 10.1542/peds.2015-3233

American Academy of Pediatrics Council on Environmental Health. (2015). Global climate change and children's health. Pediatrics, 136(5):992-997 doi: 10.1542/peds.2015-3232

Borderstep Institute. https://www.borderstep.org/digitisation-climate-protection/

Bhutta, Z. A., Aimone, A., \& Akhtar, S. (2019). Climate change and global child health: what can paediatricians do?. Archives of disease in childhood, 104(5), 417-418. https://doi.org/10.1136/archdischild-2018-316694.

Burke S.E.L., Sanson A.V. \& Van Hoorn J. (2018). The psychological effects of climate change on children. Curr Psychiatry Rep, 20(5):35. doi: 10.1007/s11920-018-0896-9.

Helldén, D., Andersson, C., Nilsson, M., Ebi, K. L., Friberg, P., \& Alfvén, T. (2021). Climate change and child health: a scoping review and an expanded conceptual framework. The Lancet. Planetary health, 5(3), e164-e175.

https://doi.org/10.1016/S2542-5196(20)30274-6

Kar N. (2009). Psychological impact of disasters on children: review of assessment and interventions. World journal of pediatrics : WJP, 5(1), 5-11. https://doi.org/10.1007/s12519-009-0001-x

Kiang, K., Graham, S., \& Farrant, B. (2013). Climate change, child health and the role of the paediatric profession in under-resourced settings. Tropical medicine \& international health : TM \& IH, 18(9), 1053-1056.

https://doi.org/10.1111/tmi.12153

Watts, N., Amann, M., Arnell, N., Ayeb-Karlsson, S., Belesova, K., Boykoff, M., Byass, P., Cai, W., Campbell-Lendrum, D., Capstick, S., Chambers, J., Dalin, C., Daly, M., Dasandi, N., Davies, M., Drummond, P., Dubrow, R., Ebi, K. L., Eckelman, M., Ekins, P., ... Montgomery, H. (2019). The 2019 report of The Lancet Countdown on health and climate change: ensuring that the health of a child born today is not defined by a changing climate. Lancet (London, England), 394(10211), 1836-1878. https://doi.org/10.1016/S0140-6736(19)32596-6

Lloyd, S. J., Bangalore, M., Chalabi, Z., Kovats, R. S., Hallegatte, S., Rozenberg, J., Valin, H., \& Havlík, P. (2018). A Global-Level Model of the Potential Impacts of Climate Change on Child Stunting via Income and Food Price in 2030. Environmental health perspectives, 126(9), 97007. https://doi.org/10.1289/EHP2916

Madrid, P. A., Grant, R., Reilly, M. J., \& Redlener, N. B. (2006). Challenges in meeting immediate emotional needs: short-term impact of a major disaster on children's mental health: building resiliency in the aftermath of Hurricane Katrina. Pediatrics, 117(5 Pt 3), S448-S453. https://doi.org/10.1542/peds.2006-0099U

Majeed, H., \& Lee, J. (2017). The impact of climate change on youth depression and mental health. The Lancet. Planetary health, 1(3), e94-e95. https://doi.org/10.1016/S2542-5196(17)30045-1 
OHCHR. Understanding Human Rights and Climate Change. https://www.ohchr.org/Documents/lssues/ClimateChange/COP21.pdf

OHCHR. The impacts of climate change on the rights of the child. https://www.ohchr.org/EN/Issues/HRAndClimateChange/Pages/RightsChild.aspx

Perera, F., Ashrafi, A., Kinney, P., \& Mills, D. (2019). Towards a fuller assessment of benefits to children's health of reducing air pollution and mitigating climate change due to fossil fuel combustion. Environmental research, 172, 55-72. https://doi.org/10.1016/j.envres.2018.12.016

Philipsborn, R. P., \& Chan, K. (2018). Climate Change and Global Child Health. Pediatrics, 141(6), e20173774. https://doi.org/10.1542/peds.2017-3774

Salas, R. N., Jacobs, W., \& Perera, F. (2019). The Case of Juliana v. U.S. - Children and the Health Burdens of Climate Change. The New England journal of medicine, 380(22), 2085-2087. https://doi.org/10.1056/NEJMp1905504.

Sheffield, P. E., \& Landrigan, P. J. (2011). Global climate change and children's health: threats and strategies for prevention. Environmental health perspectives, 119(3), 291-298. https://doi.org/10.1289/ehp.1002233

Stanberry, L. R., Thomson, M. C., \& James, W. (2018). Prioritizing the needs of children in a changing climate. PLoS medicine, 15(7), e1002627. https://doi.org/10.1371/journal.pmed.1002627.

Swaminathan, A., Lucas, R. M., Harley, D., \& McMichael, A. J. (2014). Will Global Climate Change Alter Fundamental Human Immune Reactivity: Implications for Child Health?. Children (Basel, Switzerland), 1(3), 403-423. https://doi.org/10.3390/children1030403.

United Nations. (1989). Convention on the Rights of the Child. Available at: https://treaties.un.org/doc/Treaties/1990/09/19900902\%2003-14\%20AM/Ch IV 11p.pdf

United Nations Children's Fund. (2015) Unless we act now: The impact of climate change on children. UNICEF, New York, NY. https://www.unicef.org/publications/files/Unless we act now The impact of climate_change_on_children.pdf

Waterston, T., \& Lenton, S. (2000). Public health: Sustainable development, human induced global climate change, and the health of children. Archives of disease in childhood, 82(2), 95-97. https://doi.org/10.1136/adc.82.2.95.

Wynes S. \& Nicholas K.A. (2017) The climate mitigation gap: education and government recommendations miss the most effective individual actions. Environ Res Lett, 12: 074024

Xu, Z., Etzel, R. A., Su, H., Huang, C., Guo, Y., \& Tong, S. (2012). Impact of ambient temperature on children's health: a systematic review. Environmental research, 117, 120-131. https://doi.org/10.1016/j.envres.2021.07.002,

My Green Doctor. https://www.My Green Doctor.org

Sustainable Development Goals. https://sustainabledevelopment.un.org/topics/sustainabledevelopmentgoals

Információk a szerzőről:

Kovács Zsuzsanna, házi-gyermekorvos, drkovacszsuzsa@gmail.com 